\title{
EUTHANASIA DALAM PERSPEKTIF HUKUM ISLAM
}

\author{
Arifin Rada \\ Sekolah Tinggi Agama Islam Negeri (STAIN) Ternate \\ e-mail:malukumalut@yahoo.com
}

\begin{abstract}
ABSTRAK
Euthanasia merupakan upaya untuk mengakhiri hidup seseorang ketika mengalami sakit yang tidak dapat disembuhkan, guna mengakhiri penderitaannya. Di Indonesia, euthanasia tidak dapat dilakukan dan merupakan perbuatan yang ilegal. Baik dalam hukum positif maupun dalam kode etik kedokteran diatur bahwa melakukan euthanasia tidaklah diperbolehkan. Bila dikaji dalam perspektif Hukum Islam, diatur bahwa euthanasia aktif adalah perbuatan yang diharamkan dan diancam oleh Allah SWT dengan hukuman neraka bagi yang melakukannya.
\end{abstract}

Kata Kunci: euthanasia, hukum Islam, kematian.

\begin{abstract}
Euthanasia is an attempt to end someone life when he/she has an uncurable illness, euthanasia will be done in order to release his/her from suffering his/her illness. In Indonesia, euthanasia can not be done and it is classified as an illegal act. Both in the positive law and the ethics code regulate that performing an euthanasia is not allowed. Regarded to the perspective of Islamic law, also regulated that an active euthanasia is an act that is forbidden and punishable by God with a punishment of hell for those who did.
\end{abstract}

Keywords: euthanasia, Islamic law, death.

\section{PENDAHULUAN}

Kematian, bagi sebagian besar umat manusia itu merupakan suatu hal yang tidak menyenangkan dan mungkin tidak dikehendaki. Manusia sebagai salah satu ciptaan Tuhan yang paling sempurna karena dilengkapi dengan akal, pikiran dan rasa. Dengan menggunakan akal dan pikirannya tersebut manusia mampu menciptakan teknologi untuk mempermudah dalam hal menjalankan aktifitasnya sehari-hari ( $\mathrm{Ni}$ Made Puspasutari Ujianti, dkk., 2013:41), maka dari sinilah manusia terus-menerus berusaha menunda kematian dengan berbagai cara, termasuk didalamnya temuan sains dan teknologi untuk menyembuhkan kesehatan manusia, tetapi sebaliknya, dengan adanya penemuan-penemuan sains dan teknologi tersebut, membawa suatu konsekuensi tertentu kepada ummat manusia seperti euthanasia. Padahal yang diharapkan manusia adalah sains dan teknologi memfasilitasi kehidupan manusia dengan berbagai kemajuannya. Dalam arti, pengembangan sains adalah manifestasi keinginan manusia untuk maju dan juga berkembang menyempurnakan hidupnya, dan untuk memecahkan rahasia alam. Salahsatu pengembangan sains yang membantu dan terkait langsung dengan kesehatan dan kehidupan manusia adalah teknologi kedokteran.

Teknologi kedokteran merupakan teknologi yang berkaitan langsung dengan hidup matinya manusia
(Kartono Muhammad, 1992:1). Kehidupan, serta juga kematian manusia merupakan suatu hal yang mempunyai kedudukan yang tinggi dalam nilai-nilai moral manapun, hingga setiap perlakuan terhadapnya akan menimbulkan pertanyaan-pertanyaan dari segi moral. Inilah dasar perkembangan rekayasa genetika dan bioetika atau bioteknologi sebagai suatu bidang ilmu yang kini dianggap menjadi disiplin tersendiri di dalam bidang kedokteran.

Kematian, pada umumnya dianggap sebagai suatu hal yang sangat menakutkan, namun akan dialami oleh setiap orang. Kematian merupakan suatu proses yang tidak dapat ditunda, namun kebanyakan orang tidak menghendaki bila kematian itu datang dengan segera. Kebanyakan orang berharap agar kematian tidak muncul dengan tiba-tiba. Orang bukan hanya saja ngeri menghadapi kematian itu sendiri, namun jauh lebih dari itu, orang ngeri menghadapi keadaan setelah kematian terjadi.

Tidak demikian halnya dengan orang yang telah putus asa menghadapi hidup karena penyakit yang diderita sangat menyiksanya. Mereka ingin segera mendapatkan kematian, dimana bagi mereka kematian bukan saja merupakan hal yang diharapkan, namun juga merupakan suatu hal yang dicari dan diidamkan. Terlepas daripada siap tidaknya mereka menghadapi 
kehidupan setelah kematian, mereka menginginkan kematian segera tiba.

Kematian yang diidamkan oleh pada penderita, sudah barang tentu, adalah kematian yang normal pada umumnya, jauh dari rasa sakit dan mengerikan. Kematian inilah yang dalam istilah medis disebut euthanasia yang mana dewasa ini diartikan dengan pembunuhan terhadap pasien yang tipis harapannya untuk dapat sembuh. Euthanasia sebenarnya bukanlah suatu persoalan yang baru. Bahkan euthanasia telah ada sejak dari zaman Yunani purba. Dari Yunanilah euthanasia bergulir dan berkembang ke beberapa negara di dunia, baik itu di Benua Eropa sendiri, Amerika maupun di Asia. Di negara-negara barat, seperti Swiss, euthanasia itu sudah tidak dianggap sebagai suatu pembunuhan lagi, bahkan euthanasia sudah dilegalisasi dan diatur dalam Hukum Pidana (Hardinal, 1996:7-8).

Euthanasia merupakan suatu persoalan yang cukup dilematik baik di kalangan dokter, praktisi hukum, maupun kalangan agamawan. Di Indonesia masalah ini juga pernah dibicarakan, seperti yang dilakukan oleh pihak Ikatan Dokter Indonesia (yang selanjutnya disebut IDI) dalam seminarnya pada tahun 1985 yang melibatkan para ahli kedokteran, ahli hukum positif dan ahli hukum Islam, akan tetapi hasilnya masih belum ada kesepakatan yang bulat terhadap masalah tersebut (Akh. Fauzi Aseri, 1995:51).

Demikian juga dari sudut pandang agama, ada sebagian yang membolehkan dan ada sebagian yang melarang terhadap tindakan euthanasia, tentunya dengan berbagai argumen atau alasan. Dalam Debat Publik Forum No. 19 Tahun IV, 01 Januari 1996, Ketua Komisi Fatwa Majelis Ulama Indonesia (yang selanjutnya disebut MUI) Pusat, Ibrahim Husein menyatakan bahwa, Islam membolehkan penderita AIDS dieuthanasia bilamana memenuhi syarat-syarat berikut: 1 . obat atau vaksin tidak ada; 2 . kondisi kesehatannya makin parah; 3. atas permintaannya dan atau keluarganya serta atas persetujuan dokter; 4. adanya peraturan perundang-undangan yang mana mengizinkannya. Masjfuk Zuhdi mengatakan bahwa sekalipun obat atau vaksin untuk HIV/AIDS tidak atau belum ada dan kondisi pasien makin parah tetap tidak boleh di euthanasia sebab hidup dan mati itu di tangan Tuhan (Masjfuk Zuhdi, 1996:28-29).

Pendapat tersebut merujuk pada firman Allah SWT dalam Surat Al-Mulk ayat 2:

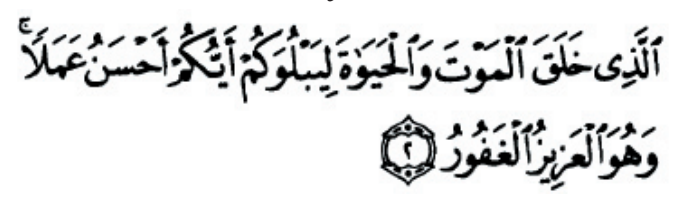

"Yang menjadikan mati dan hidup, supaya Dia menguji, siapa di antara kamu yang lebih baik amalnya dan Dia Maha Perkasa lagi Maha Pengampun" (Departemen Agama, 1989:955).

Tetapi dari pengalaman juga menunjukkan bahwa pada saat-saat ketika hal-hal yang tidak secara tegas dilarang di dalam kitab-kitab suci dan dinyatakan terlarang menurut pandangan pemuka agama, suatu saat dapat berubah.

Pro kontra terhadap tindakan euthanasia hingga saat ini masih terus berlangsung (Akh. Fauzi Aseri, 1995:51). Mengingat euthanasia merupakan suatu persoalan yang rumit dan memerlukan kejelasan dalam kehidupan masyarakat, khususnya bagi umat Islam. Maka MUI dalam pengkajian (muzakarah) yang diselenggarakan pada bulan Juni 1997 di Jakarta yang menyimpulkan bahwa euthanasia merupakan suatu tindakan bunuh diri (Forum Keadilan No. 4, 29 April 2001:45).

Secara logika berdasarkan konteks perkembangan ilmu pengetahuan, euthanasia tidak ada permasalahan karena hal ini merupakan suatu konsekuensi dari proses penelitian dan juga pengembangan. Demikian juga, dipandang dari sudut kemanusiaan, euthanasia tampaknya merupakan perbuatan yang harus dipuji yaitu menolong sesama manusia dalam mengakhiri kesengsaraannya (Amri Amir, 1997:72). Namun akan timbulah berbagai permasalahan ketika euthanasia didasarkan pada konteks yang lain seperti hukum dan agama, khususnya agama Islam. Dalam konteks hukum, euthanasia kian menjadi bermasalah karena berkaitan dengan jiwa atau nyawa seseorang oleh hukum sangat dilindungi keberadaanya. Sedangkan dalam konteks agama Islam, euthanasia menjadi bermasalah karena kehidupan dan kematian adalah berasal dari penciptaNya (Djoko Prakoso dan Djaman Andhi Nirwanto, 1984:64).

Berbicara mengenai euthanasia, yaitu khususnya euthanasia aktif, berarti juga berbicara mengenai pembunuhan, karena antara keduanya tidak dapat dipisah-pisahkan. Dalam dunia kedokteran, euthanasia dikenal sebagai tindakan yang dengan sengaja tidak melakukan sesuatu bertujuan memperpanjang hidup seseorang atau sengaja melakukan sesuatu untuk memperpendek atau juga mengakhiri hidup seorang pasien dan ini semua dilakukan untuk mempercepat kematiannya, sekaligus memungkinkan kematian yang baik tanpa penderitaan yang tidak perlu (K. Berthens, 2001:120).

Tindakan euthanasia dalam hukum Islam belum ada kejelasan dalam hal pengkategorian tindakan pembunuhan yang mana merupakan suatu jarimah. 
Sebagaimana diketahui bahwa suatu perbuatan dapat digolongkan sebagai suatu jarimah apabila memenuhi unsur-unsur jarimah. Dalam hukum pidana Islam dikenal dua unsur jarimah yaitu jarimah umum dan khusus. Yang dimaksud dengan unsur-unsur umum yaitu unsur-unsur yang terdapat pada setiap jarimah, sedangkan unsur khusus adalah unsur yang hanya ada pada jenis jarimah tertentu dan tidak terdapat pada jenis jarimah yang lain. Adapun yang termasuk unsur umum jarimah adalah sebagai berikut: Pertama, Unsur formal, merupakan adanya nash atau ketentuan yang menunjuknya sebagai jarimah. Unsur ini sesuai dengan prinsip yang menyatakan bahwa jarimah tidak terjadi bila sebelum dinyatakan dalam nash. Kedua, Unsur material, merupakan adanya perbuatan yang melawan hukum yang pernah dilakukan. Ketiga, Unsur moral, merupakan adanya niat pelaku untuk berbuat. Dengan kata lain, unsur ini berhubungan dengan tanggungjawab pidana yang hanya dibebankan atas orang mukallaf dalam keadaan bebas dari unsur keterpaksaan atau ketidaksadaran penuh (Ahmad Azar Basyir, 2001:8).

Unsur khusus dari jarimah merupakan unsur yang membedakan antara jarimah satu dengan jarimah yang lain. Misalnya unsur jarimah pembunuhan akan berbeda dengan unsur jarimah pencurian, zina, dan sebagainya.

Dalam hukum Islam, pembunuhan dikenal ada tiga macam, yaitu: Pertama, pembunuhan sengaja ( $\mathrm{Al}$ qathl al-'amd), suatu perbuatan yang direncanakan dahulu dengan menggunakan alat dengan maksud menghilangkan nyawa. Kedua, pembunuhan semi sengaja (Al-qathl sibhu al-'amd), suatu perbuatan penganiayaan terhadap diri seseorang tidak dengan suatu maksud membunuhnya, tetapi mengakibatkan kematian. Ketiga, pembunuhan karena kesalahan (Al-qathl al-khatta), pembunuhan yang terjadi karena adanya kesalahan dan tujuan perbuatannya (Djazuli, 2000:123).

Dalam hukum Islam, hingga saat ini belum ada kejelasan atau kepastian tentang eksistensi euthanasia, apakah euthanasia itu termasuk dalam jarimah atau bukan. Hal tersebut berbeda dengan Hukum Pidana Indonesia sebagaimana terkandung di dalam Pasal 344 Kitab Undang-Undang Hukum Pidana (yang selanjutnya disebut KUHP), dimana dijelaskan bahwa melakukan euthanasia merupakan suatu tindakan pidana (Natangsa Surbakti, 1998:115).

Meskipun di dalam hukum Islam itu belum ada kejelasan atau ketidakpastian dalam menentukan apakah euthanasia termasuk jarimah atau bukan, akan tetapi dalam hal euthanasia aktif yang dilakukan hanya berdasar inisiatif dokter sendiri tanpa adanya persetujuan dari pasien. Sekiranya dapat dimasukkan dalam kategori jarimah pembunuhan, dan pelaku dimungkinkan untuk dihukum sesuai dengan hukum jarimah yang ada. Pendapat demikian didasarkan atas pertimbangan karena perbuatan itu telah memenuhi syarat-syarat untuk dapat dilaksanakan dalam qishash, antara lain: 1. pembunuhan adalah orang yang baligh, sehat, dan berakal; 2. ada kesengajaan membunuh; 3. ikhtiyar (bebas dari paksaan); 4. pembunuh bukan anggota keluarga korban; 5. jarimah dilakukan secara langsung (Ahmad Azar Basyir, 2001:16).

Antara pembunuhan sengaja dengan euthanasia aktif ada suatu perbedaan yang mendasar, meski secara teknis ada persamaan. Dalam pembunuhan sengaja, terdapat suatu maksud atau tujuan yang cenderung pada tindak kejahatan. Sedangkan dalam euthanasia aktif, pengakhiran hidup pasien dilakukan secara sengaja dan terencana. Namun pembunuhan ini dilakukan atas kehendak dan permintaan pasien atau korban kepada dokter yang merawat dan maksud atau tujuan yang terdapat didalamnya cenderung pada suatu pertolongan, yang dalam hal ini menolong meringankan beban yang diderita oleh pasien.

Berdasarkan uraian di atas, berikut ini penulis merumuskan secara singkat poin-poin yang akan menjadi rumusan masalah, diantaranya yaitu apakah seorang dokter bisa mempraktekkan Euthanasia untuk meringankan seorang pasien mengakhiri hidupnya dan sejauhmanakah pandangan agama terhadap terhadap praktek Euthanasia.

\section{PEMBAHASAN}

Euthanasia merupakan upaya yang mana dilakukan untuk dapat membantu seseorang dalam mempercepat kematiannya secara mudah akibat ketidakmampuan menanggung derita yang panjang dan tidak ada lagi harapan untuk hidup atau disembuhkan. Hal tersebut memunculkan kontroversi yang menyangkut isu etika euthanasia (perilaku sengaja dan sadar mengakhiri hayat seseorang yang menderita penyakit yang tak dapat disembuhkan) tidak saja santer didiskusikan di kalangan dunia medis, akan tetapi telah merambah kemana-mana terutama para ulama Islam.

\section{Euthanasia dalam Ilmu Kedokteran}

Tugas profesional seorang dokter itu begitu mulia dalam pengabdiannya kepada sesama manusia dan tanggungjawab dokter makin tambah berat akibat kemajuan-kemajuan yang mana dicapai oleh ilmu kedokteran. Dengan demikian, maka setiap dokter perlu menghayati etik kedokteran, sehingga kemuliaan 
profesi dokter tersebut tetap terjaga dengan baik. Para dokter, umumnya semua pejabat dalam bidang kesehatan, harus memenuhi segala syarat keahlian dan pengertian tentang susila jabatan. Keahlian di bidang ilmu dan teknik baru dapat memberi manfaat yang sebesar-besarnya kalau dalam prakteknya disertai oleh norma-norma etik dan moral. Hal tersebut diinsyafi oleh para dokter di seluruh dunia, dan hampir-hampir tiap negara telah mempunyai Kode Etik Kedokteran sendiri-sendiri. Pada umumnya kode etik tersebut didasarkan pada sumpah Hipocrates, yang dirumuskan kembali di pernyataan Himpunan Dokter se-Dunia di London bulan Oktober 1949 dan diperbaiki oleh sidang ke-22 himpunan tersebut di Sydney bulan Agustus 1968 (Joko Prakoso dan Djaman Andhi Nirwanto, 1984:79).

Sejak permulaan sejarah kedokteran, seluruh umat manusia serta mengakui akan adanya beberapa sifat fundamental yang melekat secara mutlak pada diri seseorang yang baik dan bijaksana, yaitu kemurnian niat, kesungguhan dalam bekerja, kerendahan hati serta integritas ilmiah dan sosial yang tidak diragukan. Secara universal, kewajiban dokter tersebut telah tercantum di dalam Declaration of Genewa pada bulan September 1948. Dan juga kewajiban dokter tersebut tercantum pula dalam Bab II Pasal 10 dari Kode Etik Kedokteran Indonesia, yang menyatakan seorang dokter harus senantiasa ingat kewajiban melindungi hidup makhluk insani (Keputusan Menteri Kesehatan RI No. 434/Men.Kes/SK/X/1983, 1988:8).

Dengan demikian, berarti di negara manapun di dunia ini seorang dokter mempunyai kewajiban untuk menghormati setiap hidup insani mulai saat terjadinya pembuahan. Dalam hal ini berarti pula bahwasanya bagaimanapun gawatnya sakit seorang pasien, setiap dokter tetap harus melindungi dan mempertahankan hidup dari pasien tersebut. Dalam keadaan demikian mungkin pasien ini sebenarnya sudah tidak dapat disembuhkan lagi, atau sudah dalam keadaan sekarat berbulan-bulan lamanya. Akan tetapi dalam hubungan ini dokter tidak boleh melepaskan diri dari kewajiban untuk selalu melindungi hidup manusia, sebagaimana yang diucapkan dalam sumpahnya.

Karena naluri terkuat dari manusia itu adalah mempertahankan hidupnya, dan ini juga termasuk salah satu tugas dari seorang dokter, maka menurut etik kedokteran, dokter itu tidaklah diperbolehkan: menggugurkan kandungan (abortus provocatus); mengakhiri hidup seseorang pasien, yang menurut ilmu dan pengalaman tidak mungkin akan sembuh lagi (euthanasia) (Keputusan Menteri Kesehatan RI No. 434/Men.Kes/SK/X/1983, 1988:18).
Di dalam ranah ilmu kedokteran, kata euthanasia dipergunakan di dalam tiga arti, yaitu: Pertama, berpindah ke alam baka dengan tenang dan aman, tanpa penderitaan, buat yang beriman dengan nama Allah SWT di bibir; Kedua, pada waktu hidup akan berakhir, diringankan penderitaan si sakit dengan memberikan obat penenang; Ketiga, yaitu mengakhiri penderitaan hidup seseorang dengan sengaja atas permintaan pasien dan/atau permintaan dari pihak keluarganya (Keputusan Menteri Kesehatan RI No. 434/Men.Kes/SK/X/1983, 1988:21).

\section{Kode Etik Kedokteran mengenai Proses serta Eksistensi Kematian Pasien dengan Euthanasia}

Sebelumnya telah disinggung tentang pengertiam euthanasia yang tidak lain adalah mengakhiri hidup dengan cara mudah dan tanpa rasa sakit. Atau biasa juga yang disebut dengan mercy killing (mati dengan tenang). Secara garis besar, euthanasia dikelompokkan ke dalam dua kelompok, yaitu euthanasia aktif dan euthanasia pasif. Pandangan yang mengelompokkan euthanasia sebagai aktif dan pasif mendasarkannya pada cara euthanasia itu dilakukan.

Euthanasia aktif itu merupakan suatu tindakan mempercepat proses dari kematian, baik itu dengan memberikan suntikan ataupun melepaskan alat-alat pembantu medika, seperti saluran asam, melepas pemacu jantung atau sebagainya. Yang termasuk tindakan untuk mempercepat proses kematian disini adalah jika kondisi pasien, berdasarkan ukuran dan pengalaman medis itu masih menunjukkan adanya harapan hidup. Dengan kata lain yaitu tanda-tanda kehidupan masih terdapat pada penderita, ketika tindakan itu dilakukan. sedangkan euthanasia pasif, baik atas permintaan atau pun tidak atas permintaan pasein. Yaitu ketika dokter atau tenaga kesehatan lain secara sengaja tidak (lagi) memberikan bantuan medis yang mana dapat memperpanjang hidup kepada pasien (dengan catatan bahwa perawatan rutin yang optimal untuk mendampingi atau membantu pasien dalam fase terakhirnya tetap diberikan) (Kartono Muhammad, 1992:31).

Berdasarkan akibatnya, euthanasia aktif kemudian dibagi lagi menjadi dua golongan, yaitu euthanasia aktif langsung, yaitu cara pengakhiran kehidupan melalui tindakan medis yang diperhitungkan akan langsung mengakhiri hidup pasien. Misalnya dengan memberi tablet sianida atau suntikan zat yang segera mematikan, dan euthanasia aktif tidak langsung, yang menunjukkan bahwa tindakan medis yang dilakukan tidak akan langsung mengakhiri hidup pasien, akan tetapi diketahui bahwa resiko dari tindakan tersebut 
dapat mengakhiri hidup pasien. Misalnya mencabut oksigen atau alat bantu kehidupan lainnya (Kartono Muhammad, 1992:31).

Dalam hubungannya dengan kode etik kedokteran R. Soeprono dalam suatu diskusi panel mengenai euthanasia menjabarkan, bahwa segala perbuatan dokter terhadap si sakit itu bertujuan memelihara kesehatan dan kebahagiaannya. Dengan sendirinya ia harus mempertahankan dan memelihara kehidupan manusia (Majalah Panji Masyarakat, No. 318, 20 Maret 1981:40). Harus diingat bahwa, meringankan penderitaan juga menjadi kewajiban seorang dokter. Mungkin dari segi inilah sehingga beberapa ahli ada yang menerima satu macam euthanasia dan ada pula yang menerima kedua-duanya dengan beberapa pertimbangan tertentu.

Akhir-akhir ini sangat banyak sekali pertentangan hangat di seluruh dunia, mengenai kemungkinan dilakukan euthanasia. Telah diungkapkan bahwa euthanasia itu pernah terjadi di beberapa negara di dunia. Di Indonesia disinyalir berkembang euthanasia negatif. Padahal di tanah air kita ini yang berasaskan Pancasila yang sekaligus beragama, seharusnya tidak menerima euthanasia apalagi melakukannya. Tapi kasus euthanasia itu disinyalir sering terjadi di tanah air kita, yakni pada rumah sakit yang sudah memiliki Intensive Care Unit (ICU) (Hardinal, 1996:9).

Terlepas dari benar tidaknya praktek euthanasia telah terjadi di Indonesia, masalah ini menjadi cukup penting dikaji untuk mendapatkan solusinya. Sebab sebagai negara hukum, tentu saja ada konsekuensi pertanggungjawaban akan sesuatu perbuatan yang dijalankan oleh setiap warga negaranya atas dasar profesinya. Pengertian dari tanggungjawab menurut kamus hukum adalah keadaan wajib menanggung segala sesuatunya, bilamana terjadi apa-apa boleh dituntut. Berdasarkan Black Law Dictionary, istilah liability dapat diartikan sebagai suatu keadaan dimana seseorang terikat secara hukum atau keadilan untuk melaksanakan sesuatu yang dapat dipaksakan oleh suatu tindakan. Tanggungjawab hukum dari tenaga kesehatan dimaksudkan sebagai keterkaitan tenaga kesehatan terhadap berbagai ketentuan-ketentuan hukum dalam menjalankan profesinya (R.A. Antari Inaka Turingsih, 2012:271).

\section{Esensi Euthanasia dan Kedudukannya dalam Hukum Islam}

Euthanasia adalah istilah yang didapati dalam dunia kedokteran, diartikan sebagai pembunuhan tanpa penderitaan terhadap pasien yang sedang kritis (akut) atau menderita penyakit menahun serta tipis harapannya untuk sembuh kembali. Seorang pasien yang sedang sakit parah dan tidak sanggup lagi, lalu bermohon agar dokter mengakhiri hayatnya, maka dikabulkanyalah permohonan itu atas pertimbangan pasien tersebut tipis harapannya untuk dapat sembuh. Kalau pada orang seperti ini dimatikan maka kita melakukan euthanasia, yang sekarang ini tidak atau belum diterima di Indonesia, dan negara-negara lain pun masih ada yang belum menerimanya. Meskipun euthanasia itu juga demi rasa kemanusiaan yakni membebaskan orang yang hidup padahal tidak ada harapan lagi untuk hidup. Kehidupan orang secara vegetatif ini membutuhkan juga perawatan, biaya, dan sebagainya. Itu alasan-alasan yang dipertimbangkan bagi euthanasia (Ahmad Watik Pratiknya dan Abdul Salam M. Sofro, 1986:41).

Esensi daripada dilakukan euthanasia ini adalah untuk meringankan penderitaan si pasien yang telah mengalami penyakit menahun (akut) dan sudah tipis harapan untuk sembuh. Di samping itu alasan-alasan yang dipertimbangkan sehingga terjadi euthanasia adalah untuk dapat meringankan pula keluarga pasien yang ditinggalkan apalagi kalau kehidupan mereka tergolong ekonomi lemah.

Ada beberapa contoh kejadian yang mengarahkan perhatian umum kepada masalah euthanasia, karena dengan panjang lebar akan diliput oleh media massa. Tahun 1984 Gubernur Lamm dari Negara Bagian Colorado menyarankan bahwa, warga negara yang sudah tua barangkali mempunyai satu kewajiban untuk meninggal dunia. Sehingga mereka tidaklah menghabiskan bagi orang lain sumber daya yang langka. Elizabeth Bouvia, berumur 26 tahun menderita kelumpuhan total akibat trauma otak dan minta agar diizinkan mati kelaparan saja dengan menghentikan infus. Dan tahun 1985, Roswell Gilbert menjadi orang Amerika pertama yang mana didakwa dengan alasan pembunuhan karena melakukan euthanasia langsung. Istrinya mengidap penyakit Alzhaimer dan Osteoporosis, sehingga ia kehilangan semangat hidup dan menderita banyak. Setelah ia memberitahukan kepada suaminya bahwa ia ingin pergi dari dunia ini, Roswell lalu menembaknya (Thomas A. Shannon, 1995:68).

Manusia sebagai makhluk sosial selain mampu berfikir untuk maju juga mempunyai afeksi, simpati atau empati terhadap penderitaan manusia lainnya yang bisa menyebabkan timbulnya euthanasia.

Dalam hal masalah euthanasia ini, para tokoh Islam Indonesia sangat menentang dilakukannya euthanasia. Namun diantara sekian banyak ulama yang menantang euthanasia ini, ada beberapa ulama 
yang mana mendukungnya. Menurut pendapat para ulama, bahwa euthanasia boleh dilakukan apalagi terhadap penderita penyakit menular apalagi kalau tidak bisa disembuhkan. Pendapat Ibrahim Hosen ini disandarkan kepada suatu kaidah ushul fiqh: AlIrtifaqu Akhaffu Dlarurain, melakukan yang teringan dari dua mudlarat. Jadi katanya, langkah ini boleh dipilih karena ia merupakan pilihan dari dua hal yang buruk. Pertama, penderita mengalami penderitaan. Kedua, jika menular membahayakan sekali. Artinya dia menjadi penyebab orang lain menderita karena tertular penyakitnya, dan itu dosa besar. Dan beliau bukan hanya menganjurkan euthanasia pasif tapi juga euthanasia aktif (Luthfi Assyaukanie, 1998:180).

Sedangkan menurut Hasan Basri pelaksanaan euthanasia bertentangan, baik dari sudut pandang agama, undang-undang, maupun etik kedokteran. Dan lebih lanjut beliau menjelaskan bahwa persoalan hidup mati sepenuhnya hak Allah SWT. Manusia tidak bisa mengambil hak Allah SWT itu (Majalah Panji Masyarakat, No. 846, 01-15 Januari 1996:60)

Di beberapa negara Eropa dan Amerika sudah mulai banyak terdengar suara yang pro euthanasia, mereka mengadakan gerakan untuk mengukuhkannya ke dalam undang-undang. Sebaliknya mereka yang kontra euthanasia, bahwa tindakan demikian sama dengan pembunuhan. Kita di Indonesia ini sebagai umat beragama dan berPancasila percaya kepada kekuasaan yang mutlak dari Tuhan Yang Esa segala sesuatu yang diciptakanNya dan penderitaan yang dibebankan kepada makhlukNya mengandung makna dan maksud tertentu. Dokter harus mengerahkan segala kepandaiannya dan kemampuannya untuk meringankan penderitaan dan juga memelihara hidup akan tetapi tidak untuk mengakhirinya (Oemarsono Adji, 1991:219).

Menurut pendapatnya Syukron Makmun bahwa kematian itu merupakan urusan dari Allah SWT, manusia tidak dapat mengetahui kapan kematian itu menimpa dirinya. Soal sakit, menderita dan tidak kunjung sembuh itu adalah qudratullah. Kewajiban kita hanya berikhtiar. Mempercepat kematian tidak dibenarkan. Tugas dokter adalah menyembuhkan, bukanlah membunuh. Kalau dokter tidak sanggup, kembalikan kepada keluarga (Majalah Amanah, No. 27, 16-29 Juni 1989:14).

Lalu bagaimana dengan kaidah ushul fiqh yang menyatakan bahwa Al-Irtifaqu Akhaffu Dlarurain, melakukan yang teringan dari dua mudlarat. Ataukah kaidah ushul yang menyatakan Darurat membolehkan yang haram. Berdasarkan beberapa pendapat ulama di atas dan juga pembahasan batasan-batasan darurat yang telah dijelaskan pada bab terdahulu, tidak ada ditemukan pendapat yang membenarkan euthanasia ini. Dan menurut Hasan Basri sendiri kaidah itu sama sekali tidaklah dibenarkan. Kaidah tersebut dengan sendirinya bisa saja gugur bila tidak dijumpai dalil qath 'i, baik dari Al-Qur'an maupun Hadits (Majalah Panji Masyarakat, No. 846, 01-15 Januari 1996:61). Lagi pula dalam Islam, hak dan martabat manusia itu sangat dijunjung tinggi meskipun penderita misalnya banyak mengundang mudarat atau tidak.

Para ulama telah sepakat bahwa apapun alasannya, apabila tindakan itu berupa euthanasia aktif, yang berarti suatu tindakan mengakhiri hidup manusia pada saat yang bersangkutan masih menunjukkan adanya tanda-tanda kehidupan, Islam mengharamkannya.

Sedangkan terhadap euthanasia pasif, para ahli, baik dari kalangan kedokteran, ahli hukum pidana, maupun para ulama sepakat membolehkannya. Bagi mereka yang tidak setuju dengan tindakan euthanasia lebih melihat pada alasan dan perdebatan klasik. Mereka percaya bahwa yang berhak menentukan kematian itu hanyalah Allah SWT. Tugas manusia hanya berikhtiar. Seorang dokter yang melakukan euthanasia bisa saja diajukan ke pengadilan karena tuduhan membunuh, sekalipun tindakan tersebut dilakukan berdasarkan permintaan pasien.

Tetapi kelompok yang mana menyetujui praktek euthanasia ini lebih melihat pada sisi maslahat dan keadaan yang menuntut. Seorang penderita secara kronis, hanyalah akan terus menderita tanpa bisa disembuhkan. Satu-satunya cara untuk meringankan beban pasien dalam kondisi semacam itu adalah memberikan kepadanya kematian yang damai (mercy killing). Tanpa tindakan ini, para dokter dan kerabat keluarga hanya akan menyiksa atau membiarkan penderitaan sang pasien.

\section{Konsep Euthanasia dalam Hukum Islam}

Kontroversi yang mana menyangkut isu etika euthanasia (perilaku sengaja dan sadar mengakhiri hayat seseorang yang menderita penyakit yang tak dapat disembuhkan) tidak saja santer didiskusikan di kalangan dunia medis, tetapi telah merambah kemanamana terutama para ulama Islam. Isu euthanasia selalu muncul, salahsatunya karena praktek tersebut bukan hanya melibatkan pertimbangan hidup mati. Tetapi, termasuk juga pertimbangan hukum, perasaan dan etika kedokteran. Selama jenis penyakit pada manusia terus berkembang dan penyembuhan terhadapnya diyakini mustahil (apalagi dengan kadar penularan yang tinggi), para ahli medis dan hukum mulai melirik kemungkinan-kemungkinan euthanasia. 
Euthanasia, tidak ubahnya dengan menghabisi pasien yang menderita tanpa sama sekali mengakhiri penderitaan mereka. Dengan kata lain, pengobatan terhadap rasa sakit atau nyeri yang tak terbendung bukan semata dapat dilakukan dengan pembunuhan, tetapi dapat pula ditempuh dengan terapi lain. Tentu saja faktor agama akan sangat menentukan sikap seseorang terhadap derita sakit dan juga nyeri yang dialamainya. Filsafat Budha menyatakan bahwa derita sakit bersumber dari frustasi. Bagi kaum Hindu yang menyakini bahwa pain (rasa sakit dan nyeri yang berasal dari bahasa Latin poena) berarti siksaan akan lebih merasakan penderitaan nyeri dibanding seorang Muslim yang menilai penderitaan sebagai cobaan dari Tuhan atau bahkan pembersihan diri sebelum menghadap kepadaNya (Alwi Shihab, 1999:169).

Ketika orang-orang yang mana pro euthanasia menganggap bahwa kebebasan untuk melakukan apa saja terhadap diri seseorang adalah hak yang paling utama bagi mereka yang berdaya tinggi. Sebagaimana saya berhak memilih kapal untuk berlayar, atau rumah untuk dihuni, sayapun berhak untuk memilih kematian untuk dapat meninggalkan kehidupan ini. Maka Islam justru tidak sejalan dengan filosofis tersebut. Islam mengakui hak seseorang untuk hidup dan mati, namun hak tersebut merupakan anugerah Allah SWT kepada manusia. Hanya Allah SWT yang dapat menentukan kapan seseorang lahir dan kapan ia mati. Bagi mereka yang menderita bagaimanapun bentuk dan kadarnya Islam tidak membenarkan merenggut kehidupan baik melalui praktek euthanasia apalagi bunuh diri.

Islam akan menghendaki kepada setiap muslim hendaknya selalu optimis dalam menghadapi setiap musibah. Sebab seorang mu'min dicipta justru untuk berjuang, bukanlah untuk tinggal diam, dan untuk berperang bukan untuk lari. Iman dan budinya tidak mengizinkan dia lari dari arena kehidupan. Sebab setiap mukmin mempunyai kekayaan yang tidak bisa habis, yaitu senjata iman dan kekayaan budi. Tidak sedikit anjuran bagi para penderita untuk bersabar dan menjadikan penderitaan sebagai sarana pendekatan diri kepada Yang Maha Kuasa.

Agar supaya meringankan derita sakit seorang muslim diberi pelipur lara oleh Nabi Saw. dengan sabdanya, Jika seseorang dicintai Tuhan maka ia akan dihadapkan kepada cobaan yang beragam. Lain halnya dengan mereka yang tidak mendapatkan alternatif lain dalam mengatasi penderitaan dan rasa putus asa, Islam memberi jalan keluar dengan menjanjikan kasih sayang dan rahmat Tuhan, sebagaimana firman Allah SWT dalam QS. Az-Zumar ayat 53:

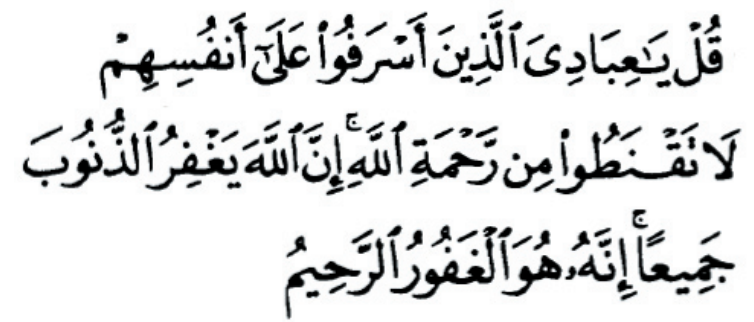

"Katakanlah: Hai hamba-hambaKu yang melampaui batas terhadap diri mereka sendiri, janganlah kamu berputus asa dari rahmat Allah. Sesungguhnya Allah mengampuni dosa-dosa semuanya. Sesungguhnya Dia-lah Yang Maha Pengampun lagi yang Maha Penyayang." (Departemen Agama RI, 1992:753)

Disinilah pentingnya peranan hukum Islam dalam menetapkan hal-hal yang halal dan haramnya suatu sikap yang diambil dalam hal euthanasia. Ketika orang diombang-ambing oleh keadaan yang sangat mendesak, karena dipengaruhi oleh tuntutan zaman atau kemajuan teknologi, dimana orang seenaknya saja bertindak, yang asalkan menurut mereka hal itu merupakan keputusan rasional tanpa melihat apakah tindakan mereka itu benar atau tidak menurut hukum, agama maupun etika.

Dalam berbagai studi dan literatur Islam, mengenai pandangan terhadap tindakan euthanasia, nampaknya ada suatu kesepakatan atau paling tidak terdapat kesamaan persepsi mengenai pengertian euthanasia. Euthanasia adalah suatu upaya yang dilaksanakan untuk dapat membantu seseorang dalam mempercepat kematiannya secara mudah akibat ketidakmampuan menanggung derita yang panjang dan tidak ada lagi harapan untuk hidup atau disembuhkan.

Begitu pula dari para tokoh Islam di Indonesia, seperti Amir Syarifuddin bahwa euthanasia adalah pembunuhan seseorang bertujuan menghilangkan penderitaan si sakit (Chuzaimah T. Yanggo, 1995: 61). Euthanasia yang sering terjadi pada umumnya dalam dunia kedokteran misalnya tindakan dokter dengan memberi obat atau suntikan. Para tokoh Islam juga sepakat bahwa eutahanasia ada dua macam yaitu euthanasia aktif dan euthanasia pasif. Euthansia aktif adalah tindakan mengakhiri hidup manusia pada saat yang bersangkutan masih menunjukkan tandatanda kehidupan (Chuzaimah T. Yanggo, 1995:62). Sedangkan euthanasia pasif adalah tindakan tindakan yang dilakukan oleh dokter atau orang lain untuk tidak lagi memberikan bantuan medis yang memperpanjang hidup pasien (Kartono Muhammad, 1992:31).

Rumusan euthanasia yang dirumuskan di atas sejalan dengan pengertian yang dirumuskan oleh komisi dari fatwa MUI, bahwa euthanasia adalah 
pembunuhan dengan didampingi oleh pertimbangan medis bagi seorang penderita atau mengidap penyakit yang mana tidak mungkin lagi disembuhkan (Majalah Panji Masyarakat, No. 846, 01-15 Januari 1996: 60). Sebenarnya dalam menelaah berbagai konsep euthanasia yang telah dirumuskan oleh para ahli, baik dari kalangan atau pakar Islam maupun diluar Islam, dasar-dasar perumusannya dapat ditemukan di dalam Al-Qur'an maupun Hadits Nabi. Hal ini sejalan dengan fleksibilitas akan sumber ajaran Islam tersebut. Misalnya dalam Al-Qur'an pada QS. AlAn'am ayat 151:

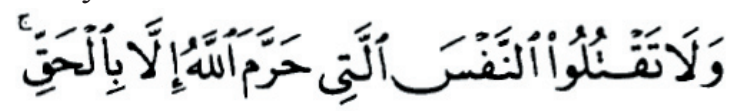

"Dan janganlah kamu membunuh jiwa yang diharamkan Allah (membunuhnya) melainkan dengan sesuatu sebab yang benar." (Departemen Agama RI, 1992:214)

Membunuh yang dimaksudkan dalam ayat di atas mengandung pengertian segala macam bentuk dan jenis pembunuhan, termasuk juga membunuh dengan jalan euthanasia itu termasuk dalam kategori ayat tersebut, yaitu membunuh secara sengaja terhadap seseorang dengan bantuan dari orang lain. Dalam pengertian ini ada subjek, yaitu orang yang membantu melakukan proses pembunuhan dan ada obyek yaitu pasien yang tengah mengalami penderitaan yang dinilai cukup tragis.

Akan tetapi pada Surat Al-An'am ayat 151 di atas ada pengecualian pembunuhan yang tidak termasuk euthanasia seperti membunuh saat berperang melawan orang kafir. Inilah yang diisyaratkan membunuh dengan alasan yang dibenarkan. Dalam pengertian yang lebih eksklusif yang mana mengarah kepada euthanasia pasif sebenarnya dapat pula ditemukan dasarnya di dalam Al-Qur'an. Karena akan dianggap tindakan bunuh diri, dimana pasien meminta sendiri untuk mempercepat kematiannya dengan diberi obat yang bisa mempercepat kematiannya, keadaan yang demikian berarti berputus asa dan mengingkari rahmat Allah SWT, sebagaimana firmanNya dalam QS. AnNisa ayat 29 yang berbunyi:

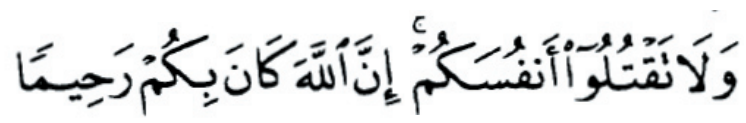

"'Dan janganlah kamu membunuh dirimu, sesungguhnya Allah Maha Penyayang kepadamu." (Departemen Agama RI, 1992:214)

Nyawa merupakan barang titipan Allah SWT, oleh karenanya tidak boleh diabaikan apalagi untuk menghilangkan secara sengaja. Islam menghendaki setiap muslim untuk dapat selalu optimis sekalipun ditimpa suatu penyakit yang sangat berat. Jadi Islam pulalah memahami bahwa euthanasia adalah suatu keinginan dalam usaha mempercepat kematian akibat ketidakmampuan menahan penderitaan.

Jadi euthanasia merupakan suatu usaha untuk membantu seseorang yang sedang mengalami sakit atau penderitaan yang tidak mungkin disembuhkan untuk dapat mempercepat kematian dengan alasan membantu menghilangkan penderitaan yang kian dirasakan, padahal sama sekali tidak dapat mengakhiri penderitaannya. Jadi hukum Islam dalam menanggapi euthanasia secara umum ini memberikan suatu konsep bahwa untuk menghindari terjadinya euthanasia, utamanya euthanasia aktif umat Islam diharapkan tetap berpegang teguh pada kepercayaannya yang memandang segala musibah (termasuk penderita sakit) sebagai ketentuan yang datang dari Allah SWT. Hal ini hendaknya dihadapi dengan penuh kesabaran dan tawakal. Dan diharapkan kepada dokter untuk tetap berpegang kepada kode etik kedokteran dan sumpah jabatannya. Dan beberapa ulama memberikan suatu konsep tentang euthanasia secara khusus bagi penderita yang penyakitnya menular. Contohnya saja bagi penderita AIDS, menurut AF. Ghazali dan salah seorang Ketua MUI Pusat HS. Prodjokusumo mengatakan bahwa, mengisolasi penderita AIDS dipandang penyelesaian yang terbaik ketimbang harus dihilangkan nyawanya (di euthanasia) (Majalah Panji Masyarakat, No. 846, 01-15 Januari 1996:61). Hal ini berarti bahwa kalau sedapat mungkin euthanasia dapat dihindari, mengapa tidak dilakukan. Karena pepatah mengatakan dimana ada kemauan disitu pasti ada jalan. Kalau dokter sudah menyerah untuk mengobati pasiennya lebih baik dikembalikan kepada keluarganya tanpa bermaksud untuk menghentikan bantuan kepada si pasien.

\section{PENUTUP \\ Kesimpulan}

Berdasarkan pada pembahasan di atas, akhirnya dapat ditarik suatu kesimpulan, Pertama, bahwa proses euthanasia dalam tinjauan kedokteran adalah apabila seorang pasien mengalami penyakit menahun dan dalam kondisi yang kritis (akut) maka seorang dokter biasanya melakukan tindakan-tindakan untuk mempercepat kematian pasiennya, misalnya dengan memberikan obat penenang dengan dosis lethal atau mencabut alat pacu jantung dengan pertimbangan untuk menolong si penderita tanpa merasa sakit. Ketika konsep euthanasia tersebut diperkenalkan di sebagian negara dunia, dan sebagian juga sudah dapat melegalkan, akan tetapi bagi negara Indonesia yang masih berpayung di bawah Pancasila tidak 
dapat melegalkan hal tersebut. Sebab secara hukum tugas dan tanggungjawab kedokteran di Indonesia, dibatasi oleh Etika Kedokteran sendiri yang isinya seorang dokter harus senantiasa mengingat kewajiban melindungi hidup makhluk insani. Juga dilarang oleh hukum positif kita yaitu KUHP, dimana dijelaskan bahwasanya melakukan euthanasia merupakan suatu tindakan pidana. Bahkan secara tegas menyebutkan barangsiapa yang merampas nyawa orang lain atas permintaan orang itu sendiri yang jelas dinyatakan dengan kesungguhan hati, diancam dengan pidana penjara, paling lama dua belas tahun.

Kedua, Tinjauan akan hukum Islam mengenai euthanasia, terutama yaitu euthanasia aktif adalah diharamkan. Karena euthanasia aktif ini dikategorikan sebagai perbuatan bunuh diri yang diharamkan dan diancam oleh Allah SWT dengan hukuman neraka selama-lamanya. Karena yang berhak mengakhiri hidup seseorang hanyalah Allah SWT. Oleh karena itu orang yang mengakhiri hidupnya atau orang yang membantu mempercepat suatu kematian seseorang sama saja dengan menentang ketentuan agama.

\section{Rekomendasi}

Untuk dapat menghadapi beberapa masalah yang berkaitan dengan adanya euthanasia ini, perlu kiranya dikemukakan saran-saran sebagai berikut:

Pertama, Bilamana pertimbangan kemampuan untuk memperoleh layanan medis yang lebih baik tidak memungkinkan lagi, baik karena biaya yang amat terbatas, ataupun karena rumah sakit yang mana lebih lengkap terlalu jauh, maka dapat dilakukan dua cara yakni: 1. menghentikan perawatan atau pengobatan, dalam artian membawa pasien pulang ke rumah; 2. membiarkan pasien dalam perawatan seadanya, tanpa ada maksud melalaikannya, apalagi menghendaki kematiannya. Oleh karena itu, umat Islam diharapkan untuk tetap berpegang teguh kepada kepercayaannya yang memandang segala musibah (termasuk menderita sakit) sebagai ketentuan yang datang dari Allah SWT. Hal itu hendaknya dihadapi dengan penuh kesadaran dan tawakkal. Justru keadaan yang kritis itu merupakan masa penentuan kokoh atau goyahnya iman seseorang. Konsekuensi dari akan dipertanggungjawabkan di kemudian hari.

Kedua, Untuk para dokter itu diharapkan agar tetap berpegang pada kode etik kedokteran dan sumpah jabatannya, sehingga tindakan yang mengarah kepada percepatan proses kematian bisa dihindari. Kode etik kedokteran dan sumpah jabatan merupakan standar profesi yang mengawal praktek dokter, sehingga praktek euthanasia bisa dihindarkan.

\section{DAFTAR PUSTAKA}

\section{Buku:}

Adji, Oemarsono, 1991, Profesi Dokter, Cetakan I, Jakarta: Erlangga.

Amir, Amri, 1997, Bunga Rampai Hukum Kesehatan, Jakarta: Widya Medika.

Aseri, Akh. Fauzi, 1995, Euthanasia Suatu Tinjauan dari Segi Kedokteran, Hukum Pidana dan Hukum Islam, dalam Problematika Hukum Kontemporer, Editor oleh Chuzaimah T. Yanggo dan Hafiz Anshary, Jakarta: Pustaka Firdaus.

Assyaukanie, Luthfi, 1998, Politik, HAM, dan Isuisu Teknologi Dalam Fikih Kontemporer, Cet. I, Bandung: Pustaka Hidayah.

Basyir, Ahmad Azar, 2001, Ikhtisar Fiqh Jinayah Hukum Pidana Islam, Yogyakarta: UII Press.

Departeman Agama RI, 1989, Al-Qur'an dan Terjemahannya, Jakarta: Toha Putera. , 1992, Al-Qur'an dan Terjemahannya, Semarang: Tanjung Mas Inti.

Djazuli, 2000, Fiqh Jinayat Upaya Menanggulangi Kejahatan dalam Islam, Jakarta: Raja Grafindo Persada.

Hardinal, 1996, Euthanasia dan Persentuhannya dengan Hukum Kewarisan Islam, Mimbar Hukum No. 6 Tahun VII, Jakarta: Ditbanpera Islam.

Moeljanto, 1978, Kitab Undang-Undang Hukum Pidana, Yogyakarta: Universitas Gadjah Mada.

Muhammad, Kartono, 1992, Teknologi Kedokteran dan Tantangannya terhadap Bioetika, Cet. I, Jakarta: Gramedia Pustaka Utama.

Prakoso, Djoko dan Djaman Andhi Nirwanto, 1984, Euthanasia Hak Asasi Manusia dan Hukum Pidana, Jakarta: Ghalia Indonesia.

Pratiknya, Ahmad Watik dan Abdul Salam M. Sofro, 1986, Islam Etika dan Kesehatan, Cet. I, Jakarta: Rajawali.

Shannon, Thomas A., 1995, Bioethics Escort, Terjemahan K. Bertens, Jakarta: Gramedia Pustaka Utama.

Shihab, Alwi, 1999, Islam Inklusif, Cet. V, Bandung: Mizan.

Turingsih, R.A. Antari Inaka, Mimbar Hukum No. 51/ DIKTI/kep/2010 Tanggal 5 Juli 2010, ISSN 0852100X, Volume 24 Nomor 2, Juni 2012, Yogyakarta: Fakultas Hukum Universitas Gadjah Mada.

Ujianti, Ni Made Puspasutari dkk, Jurnal Ilmu Hukum Kertha Wicaksana No. 64a/DIKTI/Kep./2010. ISSN 0853-6422, Volume 19 Nomor 1 Januari 2013, Denpasar: Fakultas Hukum Universitas Warmadewa Denpasar.

Yanggo, Chuzaimah T., 1995, Problematika Hukum 


\section{Islam Kontemporer, Cet. II, Jakarta: PT. Pustaka Artikel:} Firdaus.

Jurnal Hukum, Vol. I No. 1 Maret 1998, FH-UMS. Zuhdi, Masjfuk, 1996, Penderita AIDS Tidak Boleh Majalah Amanah, No. 27, tgl. 16-29 Juni 1989. Dieuthanasia, Mimbar Hukum No. 6 Tahun VII, Majalah Panji Masyarakat, No. 846, tgl. 01-15 Jakarta: Ditbanpera Islam. Januari 1996. 